\title{
Analysis of sequence diversity through internal transcribed spacers and simple sequence repeats to identify Dendrobium species
}

\author{
Y.T. Liu', R.K. Chen ${ }^{2}$, S.J. Lin'1, Y.C. Chen ${ }^{1}$, S.W. Chin ${ }^{1}$, F.C. Chen ${ }^{1}$ and \\ C.Y. Lee ${ }^{1}$ \\ ${ }^{1}$ Department of Plant Industry, \\ National Pingtung University of Science and Technology, Taiwan, \\ Republic of China \\ ${ }^{2}$ Tainan District Agricultural Research \& Extension Station, \\ Chiayi Branch Station, Taiwan, Republic of China \\ Corresponding author: C.Y. Lee \\ E-mail: culee@mail.npust.edu.tw
}

Genet. Mol. Res. 13 (2): 2709-2717 (2014)

Received March 22, 2013

Accepted September 13, 2013

Published April 8, 2014

DOI http://dx.doi.org/10.4238/2014.April.8.15

\begin{abstract}
The Orchidaceae is one of the largest and most diverse families of flowering plants. The Dendrobium genus has high economic potential as ornamental plants and for medicinal purposes. In addition, the species of this genus are able to produce large crops. However, many Dendrobium varieties are very similar in outward appearance, making it difficult to distinguish one species from another. This study demonstrated that the 12 Dendrobium species used in this study may be divided into 2 groups by internal transcribed spacer (ITS) sequence analysis. Red and yellow flowers may also be used to separate these species into 2 main groups. In particular, the deciduous characteristic is associated with the ITS genetic diversity of the A group. Of 53 designed simple sequence repeat (SSR) primer pairs, 7 pairs were polymorphic for polymerase chain reaction products that were amplified from a
\end{abstract}


specific band. The results of this study demonstrate that these 7 SSR primer pairs may potentially be used to identify Dendrobium species and their progeny in future studies.

Key words: Dendrobium; Internal transcribed spacer; Molecular marker; Simple sequence repeat

\section{INTRODUCTION}

The Orchidaceae is one of the largest and most diverse families of flowering plants. There are almost 700 genera and around 20000 species of orchids on Earth. Most Orchidaceae are rare and endangered, and have very high economic value. For instance, members of the Dendrobium genus are Orchidaceae with high economic potential as ornamental plants and for medicinal purposes. In addition, the species of this genus are able to produce large crops. Dendrobium varieties on the market are diverse and complex; however, it is difficult to distinguish one species from another, because of their very similar outward appearance before flower development, making identification problematic. To avoid mistakes in supply and demand in the Dendrobium market, it is important to use biological molecular markers as an identification method.

Molecular markers, such as simple sequence repeat (SSR), ISSRs, AFLP, and RAPDs, are efficient tools for the identification of cultivars, selection of parents for hybridization breeding, and conservation of genetic resources. Such molecular markers have already been used for the identification of Morus L. (Kalpana et al., 2012), Prunus armeniaca L. (Pedryc et al., 2009), Boesenbergia (Vanijajiva et al., 2005), Fagopyrum tataricum (Garima et al., 2012), and Lycopersicon lycopersicum L. (Meng et al., 2010) cultivars, among many other species. Molecular markers are used for the selection of parents for hybridization breeding, conservation of genetic resources, and analysis of genetic diversity, in addition to estimating the genetic diversity of different species of orchids (Huang et al., 2010). In particular, the internal transcribed spacer (ITS) technique has been frequently used to identify Orchidaceae using biological molecular markers. However, because of the diversity of the ITS technique, it is time-consuming and expensive to use. Therefore, to reduce the cost and improve the efficiency of Orchidaceae identification, more easily accessible and reliable molecular marker methods are needed to identify Orchidaceae. Recently, the SSR method has been developed to provide higher efficiency and lower cost compared to other biological molecular marker methods. This study used the original ITS sequences of 12 Dendrobium varieties to probe their phylogenetic relationship, and made use of SSR primers to identify these 12 Dendrobiums. Thus, we developed a technique to use SSR biological molecular markers to identify Dendrobium varieties. Singaporean (Yue et al., 2006) and Thai (Phuekvilai et al., 2009) researchers have also successfully used SSR markers as tools to identify Orchidaceae.

\section{MATERIAL AND METHODS}

\section{Plant materials}

Twelve plant samples were provided by Professor Chin of the National Ping Tong University of Science and Technology, Taiwan. These 12 Dendrobium samples may be distin- 
guished into 2 main groups according to their red and yellow inflorescence. The characteristic traits of these samples are presented in Figure 1 and Table 1.

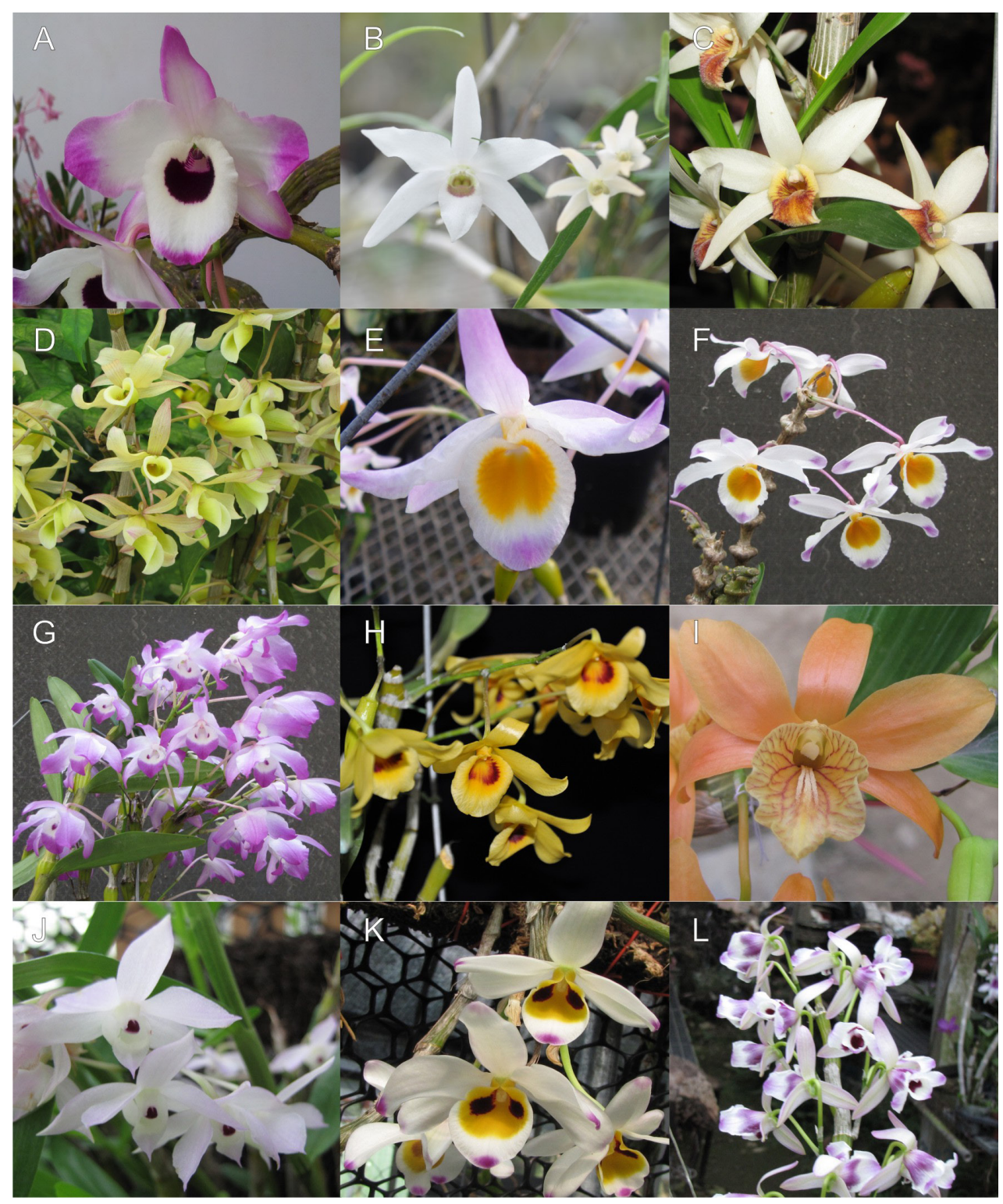

Figure 1. Pictures of the inflorescence of the 12 Dendrobium varieties studied. A. Dendrobium nobile Lindl; B. Dendrobium moniliforme (L.) Sw; C. Dendrobium heterocarpum Wall. ex. Lindl; D. Dendrobium signatum Rchb.f; E. Dendrobium findleyanum Parish \& Rchb.f; F. Dendrobium pendulum Roxb; G. Dendrobium linawianum Rchb.f; H. Dendrobium friedericksianum Rchb.f; I. Dendrobium unicum Seidenf; J. Dendrobium hercoglossum Rchb.f; K. Dendrobium wardianum Warner; L. Dendrobium nobile var. cooksonianum Rchb.f. 
Table 1. Species names, geographic distribution, color of the inflorescent, and ITS classification of 12 varieties.

\begin{tabular}{|c|c|c|c|c|}
\hline Scientific name & Range & $\begin{array}{l}\text { Color of the } \\
\text { inflorescent }\end{array}$ & Deciduous & ITS classification \\
\hline Dendrobium nobile Lindl. & $\begin{array}{l}\text { Himalayas, India } \\
\text { Bhutan, Nepal } \\
\text { Myanmar, Thailand, China, Laos } \\
\text { Vietnam }\end{array}$ & Red & Semideciduous & $\mathrm{A}$ \\
\hline Dendrobium hercoglossum Rchb.f. & $\begin{array}{l}\text { Malaysia, Thailand } \\
\text { Laos, Vietnam } \\
\text { Southern China }\end{array}$ & Red & Semideciduous & A \\
\hline Dendrobium nobile var. cooksonianum Rchb.f. & $\begin{array}{l}\text { Himalayas, India } \\
\text { Bhutan, Nepal } \\
\text { Myanmar, Thailand, China, Laos } \\
\text { Vietnam }\end{array}$ & Red & Semideciduous & A \\
\hline Dendrobium moniliforme (L.) Sw. & $\begin{array}{l}\text { Himalayas, India } \\
\text { Nepal, Bhutan } \\
\text { Myanmar, China } \\
\text { Taiwan, Korea } \\
\text { Japan, Ryukyu }\end{array}$ & Red & Semideciduous & A \\
\hline Dendrobium unicum Seidenf. & $\begin{array}{l}\text { Thailand, Vietnam } \\
\text { Laos }\end{array}$ & Orange & Deciduous & A \\
\hline Dendrobium pendulum Roxb. & $\begin{array}{l}\text { India, Myanmar } \\
\text { Thailand, Laos } \\
\text { China }\end{array}$ & Red & Deciduous & A \\
\hline Dendrobium wardianum Warner & $\begin{array}{l}\text { India, Myanmar } \\
\text { China, Thailand }\end{array}$ & Red & Deciduous & A \\
\hline Dendrobium heterocarpum Wall. ex Lindl. & $\begin{array}{l}\text { India, Sri Lanka } \\
\text { Nepal, Bhutan } \\
\text { Myanmar, Thailand, Malaysia, China } \\
\text { Sumatra, Java } \\
\text { Borneo, Sulawesi }\end{array}$ & Yellow & Semideciduous & $\mathrm{B}$ \\
\hline Dendrobium findleyanum Parish \& Rchb.f. & $\begin{array}{l}\text { Himalayas, Myanmar } \\
\text { Thailand, Laos }\end{array}$ & Red & Semideciduous & $\mathrm{B}$ \\
\hline Dendrobium signatum Rchb.f. & $\begin{array}{l}\text { Myanmar, Thailand } \\
\text { Laos, India }\end{array}$ & Yellow & Semideciduous & B \\
\hline Dendrobium linawianum Rchb.f. & Taiwan, China & Red & Semideciduous & $\mathrm{B}$ \\
\hline Dendrobium friedericksianum Rchb.f. & Thailand & Yellow & Semideciduous & $\mathrm{B}$ \\
\hline
\end{tabular}

\section{DNA extraction}

Stems or leaves were cut directly from the plant materials, frozen in liquid nitrogen, and stored at $-80^{\circ} \mathrm{C}$ before analysis.

After extracting genomic DNA from samples using an Axygen plant DNA extraction kit, the extracted genomes were diluted to $5 \mathrm{ng} / \mu \mathrm{L}$, and stored at $-20^{\circ} \mathrm{C}$.

\section{Primer design}

Fifty-three pairs of SSR primers were directly copied from the literature, including 7 pairs of primers developed from the Vanda orchid (Phuekvilai et al., 2009) and 2 pairs of primers developed from the Mokara orchid (Phuekvilai et al., 2009); 9 pairs of primers developed from the Epidendrum orchid (Pinheiro et al., 2009); 8 pairs of primers developed from the Dendrobium orchid (Boonsrangsom et al., 2008); 14 pairs of primers developed from the Dendrobium orchid (Yue et al., 2006); and 13 pairs of primers developed from the Cymbidium orchid (Huang et al., 2010).

A pair of ITS primers was designed based on the DNA sequence of a Dendrobium species with GenBank sequence accession No. EU477507.1. Consistent with the DNA sequence from 247 to 270 nucleotides, and the DNA sequence from 597 to 620 nucleotides, the forward and reverse primers were designed with a 24 -nucleotide range. 


\section{PCR amplification}

For the SSR, polymerase chain reaction (PCR) amplification was conducted in a 20$\mu \mathrm{L}$ final volume containing $20 \mathrm{ng}$ genome, $2 \mu \mathrm{L}$ dimethylsulfoxide (DMSO), $2 \mu \mathrm{L}$ PCR buffer, $400 \mu \mathrm{M}$ dNTP, $1 \mu \mathrm{L}$ of each primer (forward and reverse primers), $0.4 \mu \mathrm{L}$ Taq DNA polymerase, and $9.2 \mu \mathrm{L}$ water. The following PCR program was set to denaturation at $94^{\circ} \mathrm{C}$ for 4 min, followed by 35 cycles at $94^{\circ} \mathrm{C}$ for $40 \mathrm{~s}$, Ta at $54^{\circ}-59^{\circ} \mathrm{C}$ for $40 \mathrm{~s}, 72^{\circ} \mathrm{C}$ for $30 \mathrm{~s}$, and a final extension at $72^{\circ} \mathrm{C}$ for $10 \mathrm{~min}$, and was then held at $4^{\circ} \mathrm{C}$.

For the ITS, PCR amplification was conducted in a $50-\mu \mathrm{L}$ final volume containing 40 ng genome, $5 \mu \mathrm{L}$ DMSO, $5 \mu \mathrm{L} \mathrm{MgSO}_{4}, 5 \mu \mathrm{L}$ PFU buffer, $1000 \mu \mathrm{M}$ dNTP, $1 \mu \mathrm{L}$ of each primer (forward and reverse primers), $0.5 \mu \mathrm{L}$ PFU DNA polymerase, and $23.5 \mu \mathrm{L}$ water. The PCR program was set to denaturation at $94^{\circ} \mathrm{C}$ for $4 \mathrm{~min}$, followed by 35 cycles at $94^{\circ} \mathrm{C}$ for $40 \mathrm{~s}$, $55^{\circ} \mathrm{C}$ for $40 \mathrm{~s}, 72^{\circ} \mathrm{C}$ for $30 \mathrm{~s}$, and a final extension at $72^{\circ} \mathrm{C}$ for $10 \mathrm{~min}$, and was then held at $4^{\circ} \mathrm{C}$.

\section{ITS gene cloning}

ITS PCR products purified on a gel were used with DNA ligase to incorporate the ITS fragment into a plasmid (p-True Blue) with an internal restriction enzyme (SmaI). Subsequently, heat shock was used to transform the vector into Escherichia coli (XL1-Blue), and the resultant ITS fragment was sequenced.

\section{Analysis of phylogenetic relationships}

ITS sequences of the plant materials were confirmed 3 times, and then the Molecular Evolutionary Genetics Analysis (MEGA) software version 4.0 was used to analyze their phylogenetic relationship and construct a phylogenetic tree.

\section{RESULTS}

\section{Phylogenetic relationships of the 12 Dendrobium samples}

The 12 Dendrobium samples studied were differentiated into 2 main groups by ITS, which were designated as A and B. Group A contained D. nobile Lindl., D. hercoglossum Rchb.f., D. nobile var. cooksonianum Rchb.f., D. moniliforme (L.) Sw., D. unicum Seidenf., D. pendulum Roxb., and D. wardianum Warner, while Group B contained D. heterocarpum Wall. ex Lindl., D. findleyanum Parish \& Rchb.f., D. signatum Rchb.f., D. linawianum Rchb.f., and D. friedericksianum Rchb.f. (as shown in Figure 2). We also found that these 12 Dendrobium varieties may be separated into 2 groups according to the color of their inflorescence; red (containing more anthocyanin) and yellow (containing more carotenoids). The red group contained D. nobile Lindl., D. moniliforme (L.) Sw., D. findleyanum Parish \& Rchb.f., D. pendulum Roxb., D. linawianum Rchb.f., D. hercoglossum Rchb.f., D. wardianum Warner, and $D$. var. cooksonianum Rchb.f., while the yellow group contained $D$. heterocarpum Wall. ex Lindl., D. signatum Rchb.f., D. friedericksianum Rchb.f., and D. unicum Seidenf. As shown in Table 1 the comparisons of flower color groups and the ITS groups are quite similar, with the exception of the inflorescence D. unicum Seidenf., which is orange, and D. findleyanum 
Parish \& Rchb.f. and D. linawianum Rchb.f., which have the opposite color to the main color type within the respective ITS sequences. Furthermore, we also found that the deciduous Dendrobium cultivars also tend to reflect the ITS sequence in the A group.

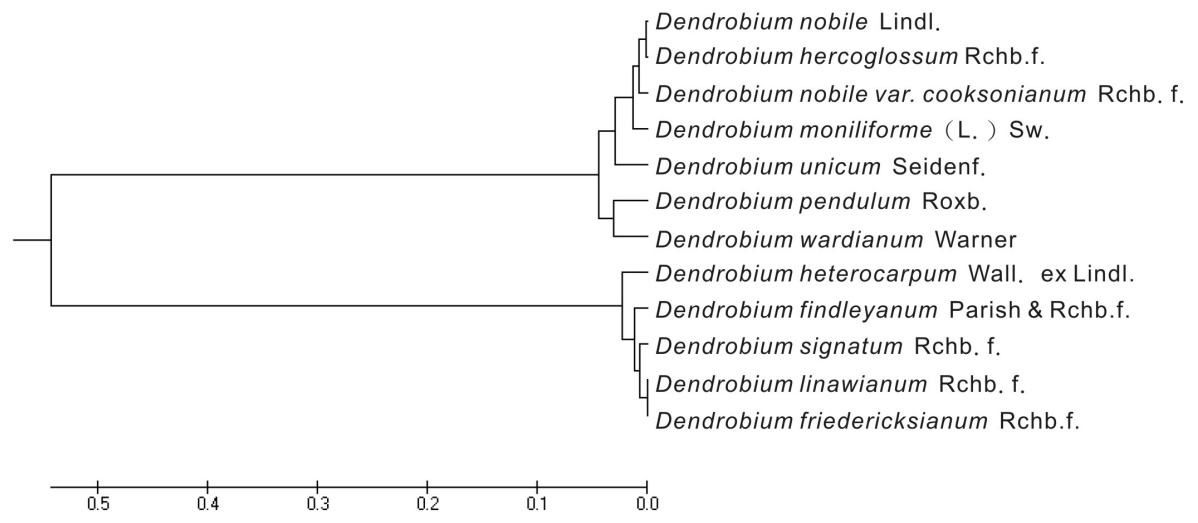

Figure 2. Dendrogram of genetic relationship among 12 Dendrobium varieties according to the ITS sequences using MEGA 4.0.

\section{Analysis of SSR marker information}

Among the 53 pairs of designed SSR primers, 7 pairs produced very specific bands for the 12 Dendrobium varieties used in this study. Specifically, 1 pair of the 9 primers was developed from Epidendrum orchids, 2 pairs of the 22 primers were developed from Dendrobium orchids, and 4 pairs of the 13 primers were developed from Chinese orchids. The selected primers and their sequences are shown in Table 2.

$\begin{aligned} & \text { Table 2. Sequences and references for the } 7 \text { pairs of SSR primers that can identify the } 12 \text { Dendrobium varieties } \\
& \text { used in this study, selected from the } 53 \text { pairs designed for orchid classification. }\end{aligned}$
\begin{tabular}{llll}
\hline Primer & \multicolumn{2}{c}{ Primer sequences } & References \\
\cline { 2 - 3 } & Forward & Reverse & \\
\hline B6-2 & TAGGATGATGCACGGGAAA & GGGGGTTTTTATCATTGAGGA & Pinheiro et al., 2009 \\
A5-3 & GGAACGGAGAAGATAAGACAACC & TGCCCTCACATGCCGTATT & Yue et al., 2006 \\
A12-3 & GTGACTCGAGCCTTGGAATACG & ACGCCGGTGAAAGAAGAAGAG & Yue et al., 2006 \\
B5-3 & GATTTATGTAGCCGACCCC & CCTGCTCCACTCACCTGTT & Huang et al., 2010 \\
B6-3 & AAAGTGACAGGGTAAGAGTGA & GGCGAAGATGTTGTTGAA & Huang et al., 2010 \\
B9-3 & AGCAACGATGGAGCAAGA & GCTGACCACGCTAACCTC & Huang et al., 2010 \\
B11-3 & GTCCCGAGCCTCACATAA & AAAGCAGTTCCATAAAGATTG & Huang et al., 2010 \\
\hline
\end{tabular}

In the analysis of $D$. nobile Lindl. using the B6-2 primer, the major bands that were identified contained 330-, 240-, and 175-bp bands. As the 240-bp band was not identified from the analysis of the other cultivars, we regarded it as specific. Hence, it is possible to use this specific 240-bp band to distinguish $D$. nobile Lindl. from the other cultivars.

When using primer B11-3 for the analysis of D. heterocarpum Wall. ex Lindl., the major bands that were identified contained 350- and 270-bp bands. For D. findleyanum Parish 
\& Rchb.f., the major bands were 270,180 , and 170 bp. For D. unicum Seidenf., the major bands were 400, 210, and 180 bp. For D. heterocarpum Wall. ex Lindl., the major-specific band was 350 bp. For D. findleyanum Parish \& Rchb.f., the major-specific band was $170 \mathrm{bp}$. For D. unicum Seidenf., the major-specific band was $210 \mathrm{bp}$. Therefore, this method could be used to identify the 12 Dendrobium species used in this study.

Among these 7 primer pairs, the B6-2 primer may be used to identify 7 of the 12 Dendrobium species used in this study, the B5-3 may be used to identify 5 species, primers A5-3 and B6-3 may be used to identify 4 species, the B11-3 may be used to identify 3 species, the B9-3 primer may be used to identify 2 species, and the A12-3 primer may be used to identify 1 species. However, of the 7 primer pairs, no single primer pair may be used to identify $D$. pendulum Roxb. The statistics are shown in Table 3 and Figure S1.

Table 3. Analysis of the polymorphic band patterns of the 12 varieties PCR using the 7 pairs of selected SSR primers.

\begin{tabular}{|c|c|c|c|c|c|c|c|}
\hline \multirow[t]{2}{*}{ ID } & \multicolumn{7}{|c|}{ Primer name } \\
\hline & B6-2 & A5-3 & A12-3 & B5-3 & B6-3 & B9-3 & B11-3 \\
\hline 1 & $\begin{array}{l}330 \mathrm{bp} \\
240 \mathrm{bp} \mathrm{SB} \\
175 \mathrm{bp}\end{array}$ & $\begin{array}{l}790 \mathrm{bp} \\
250 \mathrm{bp} \\
240 \mathrm{bp} \text { SB } \\
200 \mathrm{bp}\end{array}$ & $\begin{array}{l}400 \mathrm{bp} \\
145 \mathrm{bp}\end{array}$ & $\begin{array}{l}800 \mathrm{bp} \\
410 \mathrm{bp} \mathrm{SB} \\
305 \mathrm{bp}\end{array}$ & $155 \mathrm{bp}$ & $\begin{array}{l}270 b p \\
245 b p \\
175 b p \\
110 b p\end{array}$ & ND \\
\hline 2 & $\begin{array}{l}360 \mathrm{bp} \\
330 \mathrm{bp} \\
175 \mathrm{bp}\end{array}$ & & $\begin{array}{l}400 \mathrm{bp} \\
145 \mathrm{bp}\end{array}$ & $\begin{array}{l}590 \mathrm{bp} \mathrm{SB} \\
305 \mathrm{bp}\end{array}$ & $155 \mathrm{bp}$ & $\begin{array}{l}390 b p \\
270 b p \\
245 b p \\
110 b p\end{array}$ & ND \\
\hline 3 & $\begin{array}{l}295 \mathrm{bp} \mathrm{SB} \\
185 \mathrm{bp}\end{array}$ & $\begin{array}{l}825 \mathrm{bp} \\
200 \mathrm{bp}\end{array}$ & $145 \mathrm{bp}$ & $\begin{array}{l}780 \mathrm{bp} \\
710 \mathrm{bp} \mathrm{SB}\end{array}$ & $155 \mathrm{bp}$ & $\begin{array}{l}245 \mathrm{bp} \\
175 \mathrm{bp} \\
110 \mathrm{bp}\end{array}$ & $\begin{array}{l}350 \mathrm{bp} \text { SB } \\
270 \mathrm{bp}\end{array}$ \\
\hline 4 & $\begin{array}{l}610 \mathrm{bp} \mathrm{SB} \\
330 \mathrm{bp} \\
175 \mathrm{bp}\end{array}$ & $\begin{array}{l}200 \mathrm{bp} \\
170 \mathrm{bp} \mathrm{SB}\end{array}$ & $\begin{array}{l}400 \mathrm{bp} \\
145 \mathrm{bp}\end{array}$ & ND & $\begin{array}{l}285 \mathrm{bp} \mathrm{SB} \\
155 \mathrm{bp}\end{array}$ & $\begin{array}{l}145 \mathrm{bp} \\
200 \mathrm{bp} \mathrm{SB}\end{array}$ & ND \\
\hline 5 & $\begin{array}{l}810 \mathrm{bp} \\
330 \mathrm{bp} \\
175 \mathrm{bp}\end{array}$ & $825 \mathrm{bp}$ & $400 \mathrm{bp}$ & $\begin{array}{l}800 \mathrm{bp} \\
305 \mathrm{bp} \\
290 \mathrm{bp} \mathrm{SB}\end{array}$ & $155 \mathrm{bp}$ & $\begin{array}{l}270 \mathrm{bp} \\
245 \mathrm{bp} \\
210 \mathrm{bp}\end{array}$ & $\begin{array}{l}270 \mathrm{bp} \\
180 \mathrm{bp} \\
170 \mathrm{bp} \mathrm{SB}\end{array}$ \\
\hline 6 & $\begin{array}{l}520 \mathrm{bp} \\
185 \mathrm{bp}\end{array}$ & $160 \mathrm{bp}$ & $400 \mathrm{bp}$ & ND & $155 \mathrm{bp}$ & $245 \mathrm{bp}$ & $180 \mathrm{bp}$ \\
\hline 7 & $\begin{array}{l}690 \mathrm{bp} \text { SB } \\
360 \mathrm{bp} \\
330 \mathrm{bp} \\
175 \mathrm{bp}\end{array}$ & $\begin{array}{l}500 \mathrm{bp} \\
250 \mathrm{bp}\end{array}$ & $400 \mathrm{bp}$ & $\begin{array}{l}780 \mathrm{bp} \\
690 \mathrm{bp}\end{array}$ & $\begin{array}{l}230 \mathrm{bp} \mathrm{SB} \\
155 \mathrm{bp}\end{array}$ & $\begin{array}{l}270 \mathrm{bp} \\
245 \mathrm{bp} \\
175 \mathrm{bp} \\
110 \mathrm{bp}\end{array}$ & ND \\
\hline 8 & $\begin{array}{l}360 \mathrm{bp} \\
330 \mathrm{bp} \\
175 \mathrm{bp}\end{array}$ & $\begin{array}{l}950 \mathrm{bp} \mathrm{SB} \\
500 \mathrm{bp}\end{array}$ & $\begin{array}{l}400 \mathrm{bp} \\
145 \mathrm{bp}\end{array}$ & $\begin{array}{l}690 \mathrm{bp} \\
390 \mathrm{bp} \mathrm{SB}\end{array}$ & $155 \mathrm{bp}$ & $\begin{array}{l}270 b p \\
245 b p \\
175 b p \\
110 b p\end{array}$ & ND \\
\hline 9 & ND & $\begin{array}{l}900 \mathrm{bp} \mathrm{SB} \\
590 \mathrm{bp} \\
160 \mathrm{bp}\end{array}$ & $\begin{array}{l}305 \mathrm{bp} \text { SB } \\
145 \mathrm{bp}\end{array}$ & ND & ND & $\begin{array}{l}390 \mathrm{bp} \\
245 \mathrm{bp} \\
110 \mathrm{bp}\end{array}$ & $\begin{array}{l}400 \mathrm{bp} \\
210 \mathrm{bp} \mathrm{SB} \\
180 \mathrm{bp}\end{array}$ \\
\hline 10 & $\begin{array}{l}630 \mathrm{bp} \mathrm{SB} \\
330 \mathrm{bp} \\
215 \mathrm{bp} \mathrm{SB}\end{array}$ & $\begin{array}{l}790 \mathrm{bp} \\
160 \mathrm{bp}\end{array}$ & $145 \mathrm{bp}$ & $500 \mathrm{bp}$ & $\begin{array}{l}180 \mathrm{bp} \mathrm{SB} \\
155 \mathrm{bp}\end{array}$ & $\begin{array}{l}245 b p \\
210 b p \\
175 b p \\
110 b p\end{array}$ & $400 \mathrm{bp}$ \\
\hline 11 & $\begin{array}{l}520 \mathrm{bp} \\
250 \mathrm{bp} \mathrm{SB}\end{array}$ & $\begin{array}{l}590 \mathrm{bp} \\
160 \mathrm{bp}\end{array}$ & & $500 \mathrm{bp}$ & $155 \mathrm{bp}$ & $\begin{array}{l}185 \mathrm{bp} \mathrm{SB} \\
145 \mathrm{bp}\end{array}$ & ND \\
\hline 12 & $\begin{array}{l}810 \mathrm{bp} \\
175 \mathrm{bp}\end{array}$ & $\begin{array}{l}790 \mathrm{bp} \\
200 \mathrm{bp}\end{array}$ & $\begin{array}{l}400 \mathrm{bp} \\
145 \mathrm{bp}\end{array}$ & ND & $\begin{array}{l}300 \mathrm{bp} \mathrm{SB} \\
155 \mathrm{bp}\end{array}$ & $\begin{array}{l}270 \mathrm{bp} \\
245 \mathrm{bp} \\
175 \mathrm{bp}\end{array}$ & ND \\
\hline
\end{tabular}

$\mathrm{SB}=$ specific band; $\mathrm{ND}=$ non-decision (too complicated at the result of too many band patterns). $1=$ Dendrobium nobile Lindl; 2 = Dendrobium moniliforme (L.) Sw; 3 = Dendrobium heterocarpum Wall. ex. Lindl; 4 = Dendrobium signatum Rchb.f; 5 = Dendrobium findleyanum Parish \& Rchb.f; $6=$ Dendrobium pendulum Roxb; $7=$ Dendrobium linawianum Rchb.f; 8 = Dendrobium friedericksianum Rchb.f; $9=$ Dendrobium unicum Seidenf; $10=$ Dendrobium hercoglossum Rchb.f; 11 = Dendrobium wardianum Warner; 12 = Dendrobium nobile var. cooksonianum Rchb.f. 


\section{DISCUSSION}

In this study, we found that 12 Dendrobium cultivars may be separated into 2 main groups based on the color of their inflorescence and their deciduous characteristics, with these groupings almost matching their ITS groupings. Moreover, we found that $D$. pendulum Roxb. and $D$. wardianum Warner had very similar shaped inflorescences, and were separated into a minor group according to their genetic relationship based on the ITS sequences. A report by Korean researchers indicated that the orchids used in their study could be differentiated into 3 groups according to leaf morphology, which matched their RAPD groupings (Chung et al., 2006). Another study, also published by Korean researchers, indicates that the phylogenetic tree derived from the RAPD analysis of Cymbidiums was similar to that derived from traditional classification (Choi et al., 2006). Thus, we believe that the genetic relationship based on the ITS sequence has a degree of credibility and accuracy, based on the findings of these two similar studies. Microsatellite markers may be used to differentiate populations of Dendrobium varieties (Cai et al., 2012). Thai researchers have shown that the polymorphic band patterns of some primer pairs may be used to identify Orchidaceae cultivars, and to demonstrate their genetic relationship (Phuekvilai et al., 2009). Singaporean researchers (Yue et al., 2006) have reported that SSR markers may be used for the identification of Dendrobium varieties. The 12 Dendrobium varieties used in this study are often used as parents for a range of commercial Dendrobium varieties. D. nobile Lindl. and D. moniliforme (L.) Sw. represent 2 very important genetic sources for the breeding of new Dendrobium cultivars. According to pedigree analyses, D. nobile Lindl. and D. moniliforme (L.) Sw. constitute 41.14 and 19.43\%, respectively, of more than 500 Dendrobium cultivars (Yamamoto J, unpublished results). In this study, 3 of the 7 selected primers produced specific band patterns for D. nobile Lindl., and 1 primer of the 7 selected primers produced specific band patterns for D. moniliforme (L.) Sw. These 4 primers might represent useful tools for the identification of these 2 very important cultivars. The microsatellite markers found in this study revealed considerable genetic diversity in Dendrobium, which facilitated cultivar identification.

\section{ACKNOWLEDGMENTS}

Research supported by the Council of Agriculture, Executive Yuan (\#100AS-5.3.1-STaB, \#101AS-6.1.1-ST-ab) and National Science Council (\#101CFAA100046). Special thanks are extended to Mr. Andy Su and Chun-Hung Chen for providing the image of Dendrobium findleyanum Parish \& Rchb.f and D. nobile Lindl.

\section{$\underline{\text { Supplementary material }}$}

\section{REFERENCES}

Boonsrangsom T, Pongtongkam P, Masuthon S and Peyachoknagull S (2008). Development of microsatellite markers for Dendrobium orchids. Thai J. Genet. 1: 47-56.

Cai XY, Feng ZY, Hou BW, Xing WR, et al. (2012). Development of microsatellite markers for genetic diversity analysis of Dendrobium loddigesii Rolfe, an endangered orchid in China. Biochem. Syst. Ecol. 43: 42-47.

Choi SH, Kim MJ, Lee JS and Ryu KH (2006). Genetic diversity and phylogenetic relationships among and within species of oriental cymbidiums based on RAPD analysis. Sci. Hortic. 108: 79-85. 
Chung SY, Choi SH, Kim MJ and Yoon KE (2006). Genetic relationship and differentiation of Paphiopedilum and Phragmepedium based on RAPD analysis. Sci. Hortic. 109: 153-159.

Huang Y, Li F and Chen KS (2010). Analysis of diversity and relationships among Chinese orchid cultivars using ESTSSR markers. Biochem. Syst. Ecol. 38: 93-102.

Kalpana D, Choi SH, Choi TK, Senthil K, et al. (2012). Assessment of genetic diversity among varieties of mulberry using RAPD and ISSR fingerprinting. Sci. Hortic. 134: 79-87.

Garima K, Sanjay G and Anjana P (2012). Assessment of population genetic diversity of Fagopyrum tataricum using SSR molecular marker. Biochem. Syst. Ecol. 43: 32-41.

Meng FJ, Xu XY, Huang FL and Li JF (2010). Analysis of genetic diversity in cultivated and wild tomato varieties in Chinese market by RAPD and SSR. Agric. Sci. China 9: 1430-1437.

Pedryc A, Ruthner S, Hermán R, Krska B, et al. (2009). Genetic diversity of apricot revealed by a set of SSR markers from linkage group G1. Sci. Hortic. 121: 19-26.

Phuekvilai P, Pradit P and Surin P (2009). Development of microsatellite markers for Vanda Orchid. Kasetsart J. Nat. Sci. 43: 497-506.

Pinheiro F, Palma-Silva C, de Barros F, Félix LP, et al. (2009). Chloroplast microsatellite markers for the Neotropical orchid genus Epidendrum, and cross-amplification in other Laeliinae species (Orchidaceae). Conserv. Genet. Resour. 1: $505-511$.

Vanijajiva O, Sirirugsa P and Suvachittanont W (2005). Confirmation of relationships among Boesenbergia (Zingiberaceae) and related genera by RAPD. Biochem. Syst. Ecol. 33: 159-170.

Yue GH, Lam-Chan LT and Hong Y (2006). Development of simple sequence repeat (SSR) markers and their use in identification of Dendrobium varieties. Mol. Ecol. Notes 6: 832-834. 